\title{
Ssciendo
}

Ethics \& Bioethics (in Central Europe), 2019, 9 (1-2), 71-80

DOI:10.2478/ebce-2019-0011

\section{Transhumanism and the issue of death}

\author{
Peter Kyslan ${ }^{1}$
}

\begin{abstract}
The human issue with the concept of finality constitutes a fundamental platform for the philosophical concept of transhumanism. This paper addresses the historical-philosophical perspective of transhumanism with emphasis put on the $18^{\text {th }}$ and $19^{\text {th }}$ centuries, whereby possible anticipatory actions with respect to transhumanist thought are analyzed. In this sense, the need for a philosophical reflection on transhumanism is justified. The main part of this paper is aimed at philosophical and ethical questions related to cryonics as being one of the most dominant and feasible transhumanist practices. The characteristics and critical analysis of cryonics focuses on the problem of understanding death from a philosophical standpoint.
\end{abstract}

Keywords: transhumanism, death, culture, Enlightenment, history of philosophy, cryonics

\section{Introduction}

The present study provides insight into the broader topic of transhumanism. Transhumanist tendencies imply a number of serious philosophical issues; from issues of human nature and consciousness, through to issues of religion and ethics, to the area of the foundations of culture and science and philosophy itself. The text offers first a short historical-philosophical background of the futuristic concept of transhumanism. In the next part, the issue of death is approached from the perspective of the hypothesis that most transhumanist perspectives and projects are based on the need to delay, redefine or confront the problem of human death.

\section{Historical-philosophical perspectives of cryonics}

To define the philosophical assumptions and philosophically grasp the concept of transhumanism is a rather contradictory activity. To name the personas and ideas of the history of thought that has implied and anticipated transhumanist ideas is an effort to characterize and incorporate transhumanism into philosophy and give it an academic dimension. Transhumanism as a philosophy (or set of philosophies) is addressed by Nick Bostrom (2005), Max More (2013), Anders Sandberg (2014), among others. But many in the field of philosophical disciplines, because of the sectarian, mystical, fantastic, and futuristic nature of transhumanist concepts, reject transhumanism as a philosophy and do not subject it to research. "However, its philosophical aspects cannot be removed from transhumanism, as it seeks to find answers to the basis of philosophical questions" (Sitarčíková, 2012, p. 23). Common transhumanist questions such as what is a human?, what is death?, is progress possible?, what is human nature? have serious philosophical parameters. I believe that transhumanism is neither a science (even if it emerges from it), nor a religion, lifestyle, or philosophy, even though it possesses its own philosophy. Transhumanism is a set of ideas and expectations about the future of humanity based on the optimistic technological advancement of science (biotechnology, genetic engineering, nanotechnology, cryonics, uploading, and others). Transhumanism is a class of philosophies of life that seek the continuation and acceleration of the evolution of intelligent life, beyond its current human form and human limitations, by means of science and technology, guided by life-promoting principles and values (More, 2013). Despite the search for a particular philosophical point of view, the study does not seek to defend these tendencies. Conversely, transhumanism needs to be approached skeptically and with vigilance. Among other things, skepticism stems from the (un)scientific nature of transhumanism, and vigilance

\footnotetext{
${ }^{1}$ University of Prešov, Faculty of Arts, Institute of Philosophy, Prešov (Slovakia); email: peter.kyslan@unipo.sk
} 
also comes from the history of the invasive efforts to modify human nature (e.g. in Nazism and Communism).

The issues of transhumanism and cryonics can be approached from multiple positions, e.g. from the perspective of the philosophy of science, philosophy of life, ethics, social philosophy, philosophy of religion, philosophical anthropology, etc. In such a case, the future philosophy of man and culture should anticipate and reflect on elements and segments of their possible impact on the ethical, social and religious domains of human beings.

The following passage offers an outline of the history of philosophy and possible related relationships to the concept of transhumanism and cryonics with the emphasis put on the $18^{\text {th }}$ and $19^{\text {th }}$ centuries. In the history of philosophy, we have no thinkers that would optimistically assume a change in human nature. On the contrary, the vast majority of philosophical concepts in the history of thought are based on the paradigm of human nature as a fixed fundament. The death and the finality of human life - death as a biological necessity - are dominant cultural phenomena. We usually learn about the thinking and behavior of people of prehistoric times from burials, rituals, and so on. Death and mortality is the primary question of the oldest story in the Epic of Gilgamesh, as a man who yearns for immortality. Every mythology and religion rely on the issue of finality and human nature. We know the Greek story about Icarus and Daedal of overcoming human abilities. In antiquity, the boundaries between myth and science, and also between alchemy and technology, are often overstepped. It is as if the human desire for immortality has always been here, only its tools are changing. In his Republic, Plato also criticizes the negative interpretation of death.

Even in the philosophy of the Middle Ages, there was no consensus in recognizing eternal life efforts. For Christian medieval philosophy, eternal life was a fundamental dogma. On the contrary, the efforts of the alchemists were based on achieving eternal life on earth.

\section{Proto-transhumanist Condorcet and others}

Ideas that people themselves can develop through the application of science had been surfacing throughout the $18^{\text {th }}$ and $19^{\text {th }}$ century. One of the main representatives of Humanity,$+{ }^{2}$ George Dvorsky, called the French philosopher Marquis de Condorcet (1744-1794) a prototranshumanist and claimed that he was the first to plant the seeds of transhumanism (Dvorsky, 2008). Condorcet's work was not very significant in terms of philosophy, nor science. Being a contemporary of Voltaire, Rousseau and Turgot, his legacy was not sufficiently recognized. He is known as the author of the Sketch for a Historical Image of the Progress of the Human Mind (1795), ${ }^{3}$ and as a figure of French politics and the French Revolution. His philosophy of history does not constitute a great system, paradoxically it is incorporated within the ten periods of the Sketch. Condorcet's work is at the heart of the French Enlightenment, synthesizing a line of encyclopedists and physiocrats, philosophers and politicians, theorists, and practitioners.

It can be argued that Condorcet did not come up with his own revolutionary or new idea, but subsumed Montesquieu's historical-philosophical assumptions, Voltaire's criticism, Diderot's mathematical constructivism, and especially Turgot's idea of unstoppable progress and unrestricted improvement of humanity. Thanks to this Enlightenment "leaven" could

\footnotetext{
${ }^{2}$ Humanity Plus (also Humanity+, Inc. formerly the World Transhumanist Association) is an international organization which advocates the ethical use of emerging technologies to enhance human capacities. In 2008, as part of a rebranding effort, the WTA changed its name to "Humanity+" in order to project a more humane image. Its Articles of Incorporation were amended in 2011. The objectives of Humanity+ are: to support discussion and public awareness of emerging technologies; to defend the right of individuals in free and democratic societies to adopt technologies that expand human capacities; to anticipate and propose solutions for the potential consequences of emerging technologies; to actively encourage and support the development of emerging technologies judged to have sufficiently probable positive benefit (Humanity+ - What We Do, 2018, ๆ 2).

${ }^{3}$ Condorcet wrote the work in seclusion, in the shade of the guillotine and in a bad psychological state, but still believed in the progress of mankind. The official work was released after his death.
} 
Condorcet's concept become modern, secular, historical, universal, cosmopolitan, and in a certain sense, transhumanist.

In the Sketch, Condorcet advocated a liberal economy, free and public education, and constitutionalism. He also emphasized the superiority of reason as a way of liberating humanity from the Church, authoritarianism, and nature. Despite his utopianism, and naive speculative optimism, some of Condorcet's attitudes need to be taken seriously in the light of contemporary theoretical-scientific discourse. From a methodological point of view, it is important to mention Condorcet's effort to use mathematical principles and methods to study social sciences effectively. He was convinced that ethical, political, and social issues could be addressed through mathematical methods and prognostics.

In Condorcet's Tenth period, there are claims such as universal language, application of combinatorics, unrestricted development, life extension, and others. In this context, Condorcet's question could be mentioned: "Well, is [the] human race destined to become better, whether under the influence of new scientific and technical discoveries that will bring new sources of private well-being and public prosperity, or under more advanced principles of behavior and practical morality, or ultimately because there will be a genuine improvement in intellectual, moral, and physical abilities that can also be the consequence of improving the devices escalating and directing the use of these abilities as a result of the improvement of human natural organization?" (Condorcet, 1968, p. 163). In the second part of the paper, I will also mention Condorcet's anticipatory tendency to prolong life.

The rise of scientific physicalism in the $18^{\text {th }}$ century could also help the belief that technology could improve the human body by helping it develop. A kind of materialistic perspective (which rejects Cartesian dualism) was boldly designed in 1748 by the French doctor and materialist philosopher Julien Offray de La Mettrie in L'Homme Machine, arguing that "man is a machine so complex that it is impossible to make a clear idea about it and subsequently, as a result, to define him" (La Mettrie, 1958, p. 55). La Mettrie rejects theology, metaphysics, and the notion of the soul, and instead believes that a human being is a machine of matter that can be recognized and, thanks to this possible and growing knowledge can man become happy. "To be a machine, to feel, to think, to be able to distinguish between good and evil as well as blue and yellow, to be born with intelligence and with a safe moral instinct and yet to be an ordinary animal" (La Mettrie, 1958, p. 57). This statement is a lively starting point for transhumanist ideas and for cryonics.

Another proto-transhumanist, according to Borstom and More, was the naturalist C. Darwin, who came up with the groundbreaking evolutionary theory summarized in two key points in his book called The Origin of Species (1859): first, we can think of all biological organisms as manifestations and results of creation, without having to postulate a divine artist; and secondly, it effectively negates the notion of what was then called the fixed human species. Darwin has encouraged science and philosophy to ask whether a human being is just another level, another link in the chain of evolution, thus questioning whether he is the endpoint of evolution at all. The transhumanist answer is obvious, even some futuristic thinkers are talking about the next post-humanist evolutionary level.

After a brief attempt to outline the philosophical and historical-philosophical aspects and possible assumptions of transhumanism, we have nothing to boast about. Transhumanism, as an effort to transform a person, and also as, effectively, a battle against death, does not have philosophical support in the history of thought. However, it should be mentioned that technological tendencies do not primarily need philosophy, even its conservatism and metaphysics do not sufficiently suit it. One transhumanist theorist, M. More, contemptibly answers classical philosophers that they will become romantic partisans.

Transhumanist thought has, at its disposal, methodological and terminological elements and tools from philosophy. Even the transhumanist thinker Mark Walker in Prolegomena to any 
future philosophy (2002) suggests that rather than developing stupid small questions, the thinker himself needs to develop. In his words, "The idea ... is that we are not who should leave philosophy, but philosophy should leave us" (Walker, 2002). It suggests that soon - very soon - we will have the technological means to try to create beings that could usurp our position as the most intelligent beings on earth, and that these beings, with their excellent intellect, may prove to be better thinkers and better philosophers (Moravec, 1998; 1999).

For the future, the problem of the end of philosophy and the clichéd question of what is philosophy becomes a serious meta-philosophical issue. According to Walker, philosophy has eliminated its ambitions and has become a deflationary initiative by pragmatists, positivists, and naturalists, and therefore, in the future, it should be inflationary, i.e. ambitious like Nietzsche (Walker, 2002). What philosophy needed and anticipated from the Enlightenment was a higher intelligence than man himself. God, the absolute spirit, nature, providence was able to define and determine the possibilities of man. But in today's secular and positivist world of thinking, such "higher intelligence" is absent. Probably the complete philosophical expression of our epistemic constraints is not something we can formulate ourselves. According to transhumanist theorists, it is likely that only creatures, such as artificial intelligence, can provide the appropriate kind of philosophical theory on the subject - at least in terms of people.

In conclusion, I would like to express my belief that philosophy has a specific position between academic disciplines and culture itself so it is necessary to reflect on the possible technological and human revolution mentioned above. As such, philosophy has a particular responsibility to deal with the kinds of issues that are addressed here, with some urgency. According to the author of this paper, the philosophy of transhumanist tendencies in contemporary theoretical science should be the philosophy of responding to not-so-coherent evaluation concepts, but to gradually prepare an epistemological, methodological, and linguistic basis for future theoretical challenges.

\section{Death in Plural (Cryonics and the Transhumanist Battle with Death)}

The so-called (illusory) philosopher of proto-transhumanism, Condorcet, said in his Sketch: "It would be even absurd to assume that this improvement of the human species will continue indefinitely; but is there a presumption that a day will come when death will be the result of an extraordinary misfortune or an ever slower wear of life functions, and that in the end even the average interval between birth and the end of man cannot be determined?" (Condorcet, 1968, p. 185). For example, the Russian thinker Nikolai Fyodorov (1829-1903) was convinced that man, as the culmination of creation or evolution, has the task of perfecting himself, and in particular to get rid of his mortality. Science must strive for the immortality of man, and thus ultimately the unification of all mankind, even with those who have already died. Those will have to be resurrected. Fyodorov speaks of "immanent resurrection" (Zeňkovskij, 1991, p. 145).

The second part of the study is an attempt at a philosophical view of the issue of death in relation to cryonics. The futuristic concept of cryonics - the freezing of the human body (or the brain) with the prospect of so-called revival in the future is a scientific-futuristic concept, although in its early stages, but it is firmly correlated with current science and its ambitions. The Enlightenment belief that scientific progress will continue at the same or accelerating pace, and that everything that is not excluded from the laws of physics will become possible in the future, is the fundamental idea of the scientific optimism of cryonics. Science's meliorism also responds to human destiny and the fundamental fear of death. I believe that everything we do, beyond our natural predestination, is done to preserve, improve, and extend our lives. Perhaps it is a bold statement, but by deconstructing the nuances of human activity, we can come to that conclusion. The Neolithic discovery of agriculture, society, scripture, law, art, religion, medicine, science, the Internet, and other human inventions, arose out of the need to live better, which is at the level of humanity, but living at an individual level means living longer. Religion 
(and not only that) as one of the most expressive manifestations of human cultural activity arose because of the awareness of death and the resulting fear. Religious belief as a "calming attitude of confused instinct" (Geertz, 2000, p. 51) creates hope. Reincarnation, eternal life, or ghosts and the afterlife, do not need nature because they are purely human cultural constructs. The dominant absence of religious ideas about God, life after death, eternal life, etc., in contemporary science and transhumanism, is committed to culture to rely on itself and not to support the old biological heritage.

We all know we have to die. But immortalists say it is no longer true. Science has advanced so far that we are morally compelled to seek solutions, just as we would be morally bound to prevent a real tsunami if we knew how (Appleyard, 2008, pp. 22-23). The transhumanist M. More argues that there is no scientifically insurmountable physical boundary in how to reconstruct tissues, as he claims, "it's not like traveling in time" (Eveleth, 2014, ๆ 10).

Nanotechnology, biomedicine, biotechnology, and uploading are currently a part of life extension procedures. It does not save all life or consciousness, but (only) heals and repairs the human body. Cryonics has a special position - it faces the situation of death - it records it, redefines it and wants to overcome it. In a presentation to the most significant cryonics organization, Alcor Life Extension Foundation: Cryonics, it says: "Dying is a process, not an event. The purpose of cryonics is to intercept and stop this dying process within the window of time that it may be reversible in the future. The first few minutes of clinical death are certainly reversible, even today. There are good reasons to believe that this window will extend further in the future. That is why cryonics is sometimes implemented even long after the heart stops. Cryonics is not a belief that the dead can be revived. Cryonics is a belief that no one is really dead until the information content of the brain is lost, and that low temperatures can prevent this loss" (Cryonics Myths, 2018, ๆ 11).

\section{What is Cryonics? What is Cryo-Conservation?}

Cryonics is an experimental medical procedure that seeks to restore life to the person. A person who can no longer be treated with current medical procedures and who has been declared legally dead is placed in low-temperature storage hoping that technological progress will eventually allow him to be revived. ${ }^{4}$

For today's cryonic phase, it is not necessary for us to be able to restore cryopreserved patients (which we cannot). All that is needed is that cryonics can preserve patients in an inviolable state so that some of the possible technologies developed in the future can at once repair frost damage and reverse the original cause of death.

The patient, as cryonics refers to a dead person, is stabilized by cooling in liquid nitrogen ($196^{\circ} \mathrm{C}$ ). The freezing process causes a significant amount of cell damage. This damage can be minimized by the following suspension procedures, which include replenishing the body with cryoprotectants. The formation of harmful ice crystals can be completely suppressed by a

\footnotetext{
${ }^{4}$ Once a person is declared dead, the process of preserving it can begin and it is an intense process. First, the emergency team will move the patient from the hospital bed to an ice bed and cover him with ice mash. Then Alcor uses a heart and lung resuscitator to move the blood through the body again. They then give the body 16 different medicines to protect the cells from deterioration after death. Because patients are legally dead, Alcor can use methods that are not yet approved for routine medical purposes. When the patient is frozen and treated, they move him to the surgery site. The next step is to empty as much blood and body fluids from the person as possible and replace them with a solution that will not form ice crystals - essentially the same kind of antifreeze used to preserve organs during transplants. Thereafter, the surgeon opens the chest to gain access to the major blood vessels and attach them to a system that essentially rinses the remaining blood and changes it with medical frost resistance. As the patient will be deep-frozen, much preparatory work involves trying to ensure that ice crystals do not form inside the cells of the body. Once a patient is full of this antifreeze, Alcor can begin to cool the body by about one degree Celsius every hour, and finally approach the temperature to $-196^{\circ} \mathrm{C}$ after about two weeks. Finally, the body will find its ultimate home in the foreseeable future: upside down in the freezer, often along three others.
} 
process known as vitrification, in which the patient's body turns into a type of glass. The purpose of cryonics is to preserve life more importantly than life processes, because life processes can, in principle, be re-launched if information encoded in the structural features of the body, especially the brain, is sufficiently preserved.

Many experts ${ }^{5}$ in the field of molecular nanotechnology believe that nanotechnologies at their advanced stage will enable patients to recover from "cryonic sleep". Therefore, it is possible that the patient could be "revived" within a span of a few decades. The uncertainty of the final technical feasibility of the revival is huge, and the amount of skeptical arguments is far bigger than the optimistic ones; yet, these operations and processes are being carried out. Cryonic "trade" between the cryosphere and man (patient) is still far from guaranteeing implementation today. But as the cryonists say, "cryonics is the second worst thing that can happen to you".

If we consider the practices and advances of science that are proven today and how they could be seen in the $18^{\text {th }}$ century, we have to admit that it is quite difficult to argue with the certainty that future medical technologies will not be able to reverse the injuries that occur during cryonic suspension. In contrast, our chances of a return to this world if we choose one of the popular alternative adjustments - such as cremation or funeral - are zero. However, becoming a cryonaut requires courage, the courage to oppose the possibility of one's own death, and the courage to resist great pressure from a large part of the population (Merkle, 1994).

Since 2011, the cost of cryopreservation in the US has been between $\$ 28,000$ and $\$ 200,000$ and is often financed through life insurance. KrioRus charges $\$ 12,000$ to $\$ 36,000$. Some patients choose to cryopreserve only their head and not the whole body. Since 2016, there have been four cryopreserved storage facilities in the world; three are in the US and one is in Russia. From 2018, there has also been a facility for cryopreservation in India.

Recent research has so far revitalized and partially reconstructed a rabbit brain, but neurologically speaking, a rabbit brain is far simpler that a human brain. Some even believe that cryogenic recovery could sometimes be as common as treating the flu or repairing a broken arm.

Cryonics brings with it several serious and interesting theoretical issues. Some are related to today's freezing, but some have to do with "fantastic" future thawing. I will just mention several such issues which may certainly raise considerations and questions: e.g. the future loneliness of the cryonaut (a new life without a family after recovery); unimaginable, in the literature, the feeling of boredom of immortality; limitless possibility for the elite; the legal status of a revived person and issues of inheritance; risk of recurrent diagnosis; the risk of climatic or other disasters for cryopreservation status; the ethical problem of premature cryonization - premature suicide and euthanasia, cryothanasia (Minerva, 2018) and etc. Additional issues may emerge: What moral standing does the cryopreserved individual now have? What is the legal and moral status of individuals who end up technically alive but with severe neurological damage? And finally, who should be responsible for the care of a thawed patient who requires complex medical care? (Doyle, 2018). I, however, would like to focus on cryonics' issue connected to death, its definition and redefinition.

\footnotetext{
${ }^{5}$ The signatories of Scientists' Open Letter on Cryonics, speaking for themselves, include leading scientists from institutes such as MIT, Harvard, NASA and Cambridge University to name a few. "To whom it may concern, Cryonics is a legitimate science-based endeavor that seeks to preserve human beings, especially the human brain, by the best technology available. Future technologies for resuscitation can be envisioned that involve molecular repair by nanomedicine, highly advanced computation, detailed control of cell growth, and tissue regeneration. With a view toward these developments, there is a credible possibility that cryonics performed under the best conditions achievable today can preserve sufficient neurological information to permit eventual restoration of a person to full health. The rights of people who choose cryonics are important and should be respected. Sincerely (68 Signatories)" (Scientists' Open Letter on Cryonics, 9 3-7).
} 
Cryonics is a technology that challenges and redefines life and death. Since the 1960s, medical science has continually expanded in the so-called gray area between life and death. A life-saving and stabilizing process that brings people back to life through medical action, has been scientifically and practically deepening over the recent years. Indeed, technologies have not created this gray area, but have expanded and presented it.

In this sense, a transhumanist perspective is simply another type of medical intervention, such as contemporary medical support and life-saving. In fact, it is rather a different kind of resuscitation when the patient is very close to death, but is back. Ettinger (author of the socalled cryonics manifesto The Prospect of Immortality) and other cryonists have argued that the frozen are not corpses, but should be seen as those awaiting treatment (Ettinger, 1964).

The development of medical intervention technology in the brain has progressed, and increasing controversy has emerged about the definition and state of death that cryonics works with. Leading brain death theorists have recently concluded that efforts to define the ultimate death standard should be abandoned in favor of a more pragmatic set of questions. The advancement of biotechnology forces Western societies to finally repudiate outdated modern images of the body and soul, and rather prioritize the medical optics of tiered consciousness rather than accept old static rights and values. The relevance of these questions is also confirmed by the impulses to overcome the dualism of death and life, and prenatal discussions on genomes, the beginning of life, and of the viability or non-viability of the fetus. The near future of biotechnologists regarding the normal holistic process of fertilization and gestation in nonmothers can be realized within a few years. Even these more realistic processes open up similar ethical and philosophical issues of the beginning and end of life, as in the case of the moredistant cryonization.

Both classical and current definitions of death (clinical ${ }^{6}$ and biological ${ }^{7}$ ) will need to be modified. Some theorists promote one "death" as a single indicator of the human condition, while others emphasize multiple "deaths" and emphasize the necessary need to recognize new brain death standards. The future will be represented by a shift towards personality-based consciousness and ethics as a means of addressing not only brain death, but also with ectopic pregnancies, intelligent systems, cyborgs - human machines, and other new forms of life that we create with the help of science and technology.

The struggle between anthropocentrists and biofundamentalists on the one hand and transhumanists on the other will be wild. Any proposal for extending human capabilities beyond our "natural" and "God-given" predestination will have ethical, political, and legal consequences. It is nothing new, history and the history of thought often show the political legitimacy of human life norms - norms like nature, humanity, civilization, culture, morality which become norms that are political and discursive. So, given the growing secularization of human life, the tangible benefits of new technologies and the intrinsic logic of Enlightenment values, transhumanism is developing a new bioethics that relativizes old bases and platforms. From a religious point of view, this issue is probably the most difficult. For atheists who do not believe in the afterlife, cryonics represent the only chance of life after "death" (Shaw, 2009, p. 519), if they are interested in it. Transhumanism can act as a philosophy of life that fulfills some of the same functions as religion possesses, without any reference to force majeure, supernatural subject, faith, and without other essential features of religion (More, 2013, p. 11). Those who have strong religious views may tend to consider transhumanism to compete with their faith.

\footnotetext{
${ }^{6}$ Clinical death is the medical term for cessation of blood circulation and breathing, the two necessary criteria to sustain human and many other organisms' lives.

7 Biological death is permanent and incompatible damage to brain tissue due to oxygen deficiency and / or mechanically. Ultimate, irreversible state.
} 
Transhumanism and cryonics speak of yet another kind of death - the information-theoretic death - which changes the view and previous ideas, while building a new metaphysics of man and his death. Information-theoretic death is related to the above-mentioned uploading (uploading brain information to computer systems) and this process is one of the resurrecting processes of cryonics. The information-theoretic death in futurist ideas overcomes clinical and biological death in a way that is more mortal than death in the classical sense. After it, there is no turning back, but if it is prevented, a way back may be possible. For cryonists, digital immortality is a very seductive and important topic: "Cryonic preservation of other people and even animals may be useful - my personal digital immortality, as they have memories about me" (Turchin, 2018, p. 31).

Ralph Merkle defined information-theoretic death as follows: "A person is dead according to the information theoretic criterion if their memories, personality, hopes, dreams, etc. have been destroyed in the information theoretic sense. That is, if the structures in the brain that encode memory and personality have been so disrupted that it is no longer possible in principle to restore them to an appropriate functional state then the person is dead. If the structures that encode memory and personality are sufficiently intact that inference of the memory and personality are feasible in principle, and therefore restoration to an appropriate functional state is likewise feasible in principle, then the person is not dead" (Merkle, 1994, p. 9). The defeat of old dualism simply says that if we can stabilize the brain, freeze, not clone, upload, and so on, we are never completely dead.

In socio-cultural evolution, the role of genes is played by cognitive systems - meme $^{8}$ that are incorporated into individual brains or social organizations or are stored in books, computers, and other information media. However, most of the knowledge gained by one person will disappear when it is biologically dead. Only a small part of this knowledge is stored outside the brain or transmitted to others. Further development of humanity under transhumanism would be much more effective if all the lessons learned through experience could be edited and preserved.

This requires the effective immortality of cognitive systems that define individual and collective ideas: what survives is not material (body or brain) but has a cybernetic and information-theoretic organizational structure. We can call it "cyber-immortality" (Turchin, 1991). We could imagine our realization by means of a very advanced human-machine system, where the boundary between organic (brain) and artificially organic, or electronic, media (computers) becomes irrelevant. The death of the biological component of the system would no longer mean the death of the entire system.

Cyber-immortality can be understood by transhumanist thought as the ultimate goal or value, capable of motivating long-term scientific and cultural activity. Similar memetical references to the future would remain in full form with mankind at all times. Campbell, by analogy, connects with the metaphysical immortality of the "soul" in heaven in a traditional religions sense to motivate an individual to live morally (Campbell, 1979). Similarly, Turchin talks about a similar creative immortality (Turchin, 1991), which is the driving force of artists, authors, or scientists hoping to survive "forever" in their works that leave offspring. But the futuristic idea of uploading reason and its autonomy in cyberspace overcomes all the notions and inscriptions of information to the present and raises ethical, legal, and other philosophical issues and concerns.

Molecular reconstruction of the brain cannot be spoken of today, but some human brain simulation in this sense is possible. A computer, robot, based on information, voice color, attitudes, and photography can simulate a particular person. From the anthropological point of

\footnotetext{
${ }^{8}$ Meme - the term for a cultural equivalent of a gene - a replicating unit of cultural information. This term was first used in 1976 by Richard Dawkins in his book The Selfish Gene. The word meme is derived from the Greek mimema - imitating.
} 
view, anthropology and human definitions can be deconstructed. We can say that death is the basis of consciousness, normative law, and human existence. The loss of death is likely to radically change who or what is human or creation. The philosopher of consciousness, Paul Churchland, claims: "If machines come to simulate all our inner cognitive activities, to the last calculation details, denying them the status of real persons would be nothing but a new form of racism" (Churchland, 1998, p. 120).

\section{Conclusion}

The presented considerations had two areas and roles, firstly to suggest controversy over the philosophical and historical-philosophical foundations of transhumanism, with the emphasis put on cryonics, and to ask a meta-reflexive question about the future nature of philosophy and, secondly, to think about the problems of cryonics and its redefinition of death. The present research and theoretical optics represent only a basic and a partial engagement with respect to the given issue.

Translated by Maroš Buday

\section{Acknowledgement}

The article is an output of VEGA project 1/0880/17 Filozofia dejín v osvietenstve: Dejiny ako fundamentálny moment sebainterpretácie človeka v kontexte filozofie 18. storočia [Philosophy of History in the Enlightenment: History as a Fundamental Moment of Human SelfInterpretation in the Context of $18^{\text {th }}$ Century Philosophy] supported by the Ministry of Education, Science, Research and Sport of the Slovak Republic.

\section{References}

APPLEYARD, B. (2008): How to live forever or die trying: on the new immortality. London: Pocket Books.

BOSTROM, N. (2005): A History of transhumanist thought. In: Journal of Evolution and Technology, 14(1), pp. 1-25.

CAMPBELL, D. T. (1979): Comments on the sociobiology of ethics and moralizing. In: Behavioral Science, 24, pp. 37-45.

CHURCHLAND, P. (1998): Matter and consciousness: A contemporary introduction to the philosophy of ind. Cambridge, MA: The MIT Press.

CONDORCET, J. A. (1968): Náčrt historického obrazu pokroků lidského ducha [Sketch for a historical picture of the progress of the human mind] Praha: Academia.

CRYONICS MYTHS (2018): [online] [Retrieved November 22, 2018]. Available at: https://www.alcor.org/cryomyths.html\#myth3

DOYLE, D. J. (2018): What does it mean to be human? Life, death, personhood and the transhumanist movement. Cham: Springer.

DVORSKY, G. (2008): Marquis de Condorcet, Enlightenment proto-transhumanist. Institute for Ethics and Emerging Technologies. [online] [Retrieved November 22, 2018]. Available at: http://ieet.org/index.php/IEET/more/2250/

ETTINGER, R. (1964): The prospect of immortality. New York: Doubleday.

EVELETH, R. (2014): Cryopreservation: 'I freeze people to cheat death'. [online] [Retrieved November 26, 2018]. Available at: http://www.bbc.com/future/story/20140821-i-will-befrozen-when-i-die

GEERTZ, C. (2000): Interpretace kultur [The interpretation of cultures]. Praha: Sociologické nakladatelství. 
HUMANITY+ - WHAT WE DO (2018): [online] [Retrieved November 11, 2018]. Available at: https://humanityplus.org

LA METTRIE, J. O. de (1958): Člověk stroj [Man a machine]. Praha: Nakladatelství Československé akademie věd.

MERKLE, R. C. (1992): The technical feasibility of cryonics. In: Medical Hypotheses, 39, pp. 6-16.

MERKLE, R. C. (1994): The molecular repair of the brain. In: Cryonics Magazine, 15(1-2), pp. 16-30.

MINERVA, F. (2018): The ethics of cryonics: Is it immoral to be immortal? Palgrave: Pivot. MORAVEC, H. (1998): Robot: Mere machine to transcendent mind. Oxford: Oxford University Press.

MORAVEC, H. (1999): Rise of the robots. In: Scientific American, 281(6), pp. 124-135.

MORE, M. (2013): The philosophy of transhumanism. Oxford: John Wiley \& Sons. [online] [Retrieved November 22, 2018]. Available at: http://media.johnwiley.com.au/product_data /excerpt/10/11183343/1118334310-109.pdf

SANDBERG, A. (2014): Ethics of brain emulation. In: Journal of Experimental \& Theoretical Artificial Intelligence, 26(3). [online] [Retrieved November 22, 2018]. Available at: http://www.aleph.se/papers/Ethics\%20of\%20brain\%20emulations\%20draft.pdf

SCIENTISTS' OPEN LETTER ON CRYONICS. [online] [Retrieved December 11, 2018]. Available at: https://www.biostasis.com/scientists-open-letter-on-cryonics/

SHAW, D. M. (2009) Cryoethics: Seeking life after death. In: Bioethics, 23(9), pp. 515-521. SITARČIKOVÁ, Z. (2012): O šl'achtení človeka: nanotechnológie, transhumanizmus a l’udská prirodzenost' [On human resources: Nanotechnology, transhumanism and human nature]. Bratislava: Veda.

SORGNER, L. (2009): Nietzsche, the overhuman, and transhumanism. In: The Journal of Evolution and Technology, 20(1), pp. 29-42.

TURCHIN, V. (1991): Cybernetics and philosophy. In: F. Geyer (ed.): Proc. 8th Int. Conf. of Cybernetics and Systems. Salinas, CA: Intersystems, pp. 61-74.

TURCHIN, V. (2018): Digital immortality: Theory and protocol for indirect mind uploading. [online] [Retrieved April 22, 2019]. Available at: https://philpapers.org/rec/TURDIT

WALKER, M. A. (2002): Prolegomena to any future philosophy. In: Journal of Evolution and Technology, 10 [online] [Retrieved November 22, 2018]. Available at: http://jetpress.org/volume10/prolegomena.html

ZEŇKOVSKIJ, V. V. (1991): Istorija russkoj filosofii [A history of Russian philosophy], vol. 2. Leningrad: EGO. 